\title{
Pengaruh Keterlibatan, Kemampuan Teknis, dan Pelatihan Kerja Pemakai pada Kinerja Sistem Informasi Akuntansi
}

\author{
Ni Putu Krisna Dewi ${ }^{1}$ \\ Fakultas Ekonomi dan Bisnis \\ Universitas Udayana, Indonesia \\ Email: npkrisna03@gmail.com
}

\author{
I Dewa Nyoman Wiratmaja ${ }^{2}$ \\ Fakultas Ekonomi dan Bisnis \\ Universitas Udayana, Indonesia
}

\begin{abstract}
ABSTRAK
Tujuan dari penelitianini adalahuntuk mengetahui Pengaruh Keterlibatan, Kemampuan Teknis, dan Pelatihan Kerja Pema kai Pada Kinerja Sistem Informasi Akuntansi. Penelitian ini dilakukan di Dinas Perindustrian dan Perdagangan Kota Denpasar. Jumlah responden sebanyak 50 orang responden, dengan metode non-probability sampling. Teknik analisis yang digunakan adalah teknik analisis regresi linear berga n da. Ha sil analisis menunjukkan bahwa, keterlibatan, kemampuan teknis, dan pelatihan kerja pemakai berpengaruh positif pada kinerja sistem informasi akuntansi. Hal ini menunjukkan bahwa semakin tinggi keterlibatan pemakai, kemampuan teknis, dan pelatihan kerja yang dimiliki pegawai DinasPerind ustrian da n Perdagangan Kota Denpasar maka kinerja sistem informasi akuntansi yang dihasilkan akan semakin meningkat.
\end{abstract}

Kata Kunci: Keterlibatan Pemakai; Kemampuan Teknis Pemakai; Pelatihan Kerja Pemakai; KinerjaSistem Informasi Akuntansi.

\section{The Influence of Involvement, Technical Capability, and User Job Training on Accounting Information System Performance}

\section{ABSTRACT}

The purpose of this study was to determine the Effect of Engagement, Technical Capability, and User Job Training on Accounting Information System Performance. This research was conducted at the Department of Industry and Trade Denpasar City. The number of respondents was 50 respondents, with non-probability sampling method. The analysis technique used is multiple linear regression analysis techniques. The analysis shows that the involvement, technical ability, and work training of users has a positive effect on the performance of accounting information systems. This shows that the higher the involvement of users, technical capabilities, and job training owned by Denpasar City Industry and Trade staff the performance of the accounting information system produced will increase.

Keywords: $\quad$ User Involvement; User Technical Capability; User Job Training; Accounting Information System Performance.

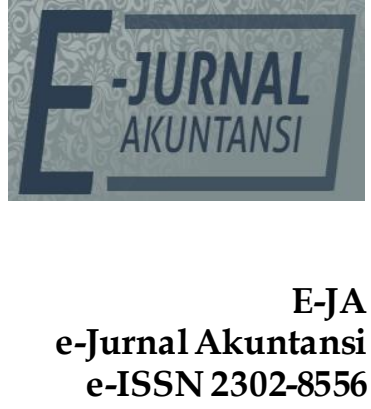

Vol. 30 No. 4

Denpasar, April 2020

Hal. 979-992

Artikel Masuk: 7 Januari 2020

Tanggal Diterima: 6 Maret 2020 


\section{PENDAHULUAN}

Instansi yang terkomputerisasi dan terintegrasi mempunyai teknologi yang di dukung oleh aplikasi pendukung modern yang canggih, mampu memberikan dampak yang positif bagi kinerja instansi dalam membuat laporan keuangan yang akurat, tepat waktu dan dapat dipercaya. Salah satu cara untuk mengetahui tingkat kinerja perusahaan dapat dilihat dari kinerja sistem informasi akuntansi yang digunakan di perusahaan tersebut.

Kinerja sistem informasi akuntansi dapat dipengaruhi dari berbagai faktor. Pada penelitian Choe (1996) mengungkapkan bahwa terda pat beber a pa faktor yang berpengaruh terhadap kinerja sistem informasi akuntansi, yaitu keterlibatan pemakai, kemampuan teknis pemakai sistem informasi, dan ketentuan pelatihan dan pendidikan pemakai sistem informasi. Menurut Almilia (2007) mengemukakan dari penelitian yang sudah dilakukan, faktor-faktor y ang memengaruhi kinerja SIA hanya dukungan manajemen puncak, sedangkan faktor-faktor lainnya seperti pelatihan dan pendidikan, keterlibatan pemakai serta kemampuan teknik personal tidak berpengaruh terhadap kinerja SIA. Hasil tersebut berbeda dengan hasil penelitian Ayu (2014) yang dalam penelitiannya mendapatkan hasil bahwa keterlibatan, kemampuan, dan pelatihan kerja pemakai berpengaruh signifikan terhadap kinerja SIA. Penelitian tersebut juga mendapatkan hasil yang sama dengan penelitian yang dilakukan oleh Suar dika \& Surya (2016) bahwa keterlibatan, kemampuan, pelatihan dan pendidikan pemakai berpengaruh positif dan signifikan terhadap kinerja SIA yang diukur dengan kepuasan pemakai. Meiryani (2014) dalam penelitiannya mend apatkan hasil bahwa partisipasi pengguna sistem informasi berpengaruh positif signifikan terhadap kualitas SIA. Napitupulu (2015) mendapatkan hasil yang sama dengan Meiryani (2014) yaitu keterlibatan pengguna berguna dan memiliki efek positif pada kualitas sistem informasi dan kepuasan pengguna itu sendiri. Sedangkan Daryani (2013) dalam penelitiannya mendapatkan hasil bahwa hanya keterlibatan pemakai yang tidak berpengaruh terhadap kinerja SIA, namun kemampuan teknik personal, dukungan manajemen puncak, pelatihan dan pendidikan pemakai berpengaruh terhadap kinerja SIA. Sedangkan Jones (2008) dalam Galang (2014) mendapatkan hasil bahwa hanya pelatihan dan pendidikan yang berpengaruh positif terhadap kinerja SIA, dan keterlibatan pemakai dan kemampuan teknik personal tidak berpengaruh positif dan signifikan terhadap kinerja SIA.

Dinas Perindustrian dan Perdagangan Kota Denpasar merupakan salah satu sarana pelayanan yang dibentuk oleh Pemerintah guna meningkatkan efesiensi perdagangan dalam negeri. Bantuan yang rutin diberikan oleh Dinas Perindustrian dan Perdagangan adalah dengan mengadakan pelatihan-pelatihan kepada industri kecil dan menengah di Kota Denpasar, hal tersebut guna mencetak wirausaha sebanyak-banyaknya, karena wirausaha terbukti mampu meningkatkan kesejahteraan masyarakat melalui peningkatan pendapatan akibat ekonomi yang berkembang. Dinas Perindustrian dan Perdagangan Kota Denpasar membutuhkan perencanaan dan anggaran sebelum mengadakan suatu pelatihan serta adanya proses pencatatan keuangan setelah mengadakan suatu pelatihan. Perencanaan dan anggaran serta pencatatan keuangan dibantu dengan adanya sistem akuntansi yang terkomputerisasi. Saat ini Dinas Perindustrian dan 
Perdagangan menggunakan sistem informasi akuntansi yang diberi nama Sistem Informasi Pengelolaan Keuangan Daerah (SIPKD).

SIPKD adalah aplikasi terpadu yang dipergunakan sebagai alat bantu pemerintah daerah untuk meningkatkan efektivitas implementasi dari berbagai regulasi bidang pengelolaan keuangan daerah yang berdasarkan asas efisiensi, ekonomis, efektif, transparan, akuntabel, dan auditabel. Dimana Dinas Perindustrian dan Perdagangan Kota Denpasar melaporkan pertanggungjawaban keuangannya kepada BPKAD (Badan Pengelolaan Keuangan dan Aset Daerah) Kota Denpasar.

Menurut Kepala Sub Bagian Keuangan Dinas Perindustrian dan Perdagangan Kota Denpasar, kemampuan pegawai yang kurang optimal dalam mengoperasikan SIPKD karena tidak semua pegawai belum memahami SIPKD tersebut, pegawai masih sulit untuk menggunakan SIPKD, disiplin kerja pegawai masih kurang dan tidak tepat waktu, pegawai yang mengoperasikan SIPKD berlatar belakang pendidikan akuntansi juga masih minim di bagian keuangan. Sebagian besar pegawai yang mengoperasikan SIPKD berlatar belakang pendidikan sarjana komputer dan sarjana teknik. Akibatnya laporan keuangan yang seharusnya dilaporkan ke BPKAD Kota Denpasar paling lambat tanggal 10 setiap bulannya, menjadi terlambat dalam melaporkan laporan keuangan setiap bulannya. (Disperindag 02/09/19 10:00).

Adanya ketidak konsistenan pada penelitian-penelitian terdahulu serta adanya permasalahan dalam Dinas Perindustrian Dan Perdagangan Kota Denpasar maka peneliti ingin meneliti kembali mengenai beberapa faktor yang memengaruhi kinerja SIA yaitu keterlibatan, kemampuan teknis, dan pelatihan kerja pemakai sebagai variabel bebas. Variabel terikat dalam penelitian ini adalah kinerja SIA yang diukur dengan kepuasan pemakai pada Dinas Perindustrian dan Perdagangan Kota Denpasar.

Sistem informasi akuntansi tidak akan menghasilkan informasi bagi organisasi apabila tidak ada pemakai yang mengoperasikan sistem tersebut. Oleh karena itu keterlibatan pemakai sistem informasi sangat diperlukan agar sistem informasi dapat beroperasi secara maksimal. Penelitian yang dilakukan Komara (2005), dan Ayu (2014) menemukan bahwa keterlibatan pemakai dalam pengembangan sistem informasi akuntansi berpengaruh positif terhadap kinerja sistem informasi akuntansi. Menurut Acep (2005) pengaruh keterlibatan pemakai dalam pengembangan sistem berpengaruh positif dan signifikan terhadap kinerja SIA. Tjhai (2002) berpendapat bahwa keterlibatan pemakai yang semakin sering akan meningkatkan kinerja SIA dikarenakan adanya hubungan yang positif antara keterlibatan pemakai dalam proses pengembangan sistem informasi dalam kinerja SIA. Penelitian tersebut diatas memiliki kesamaan dengan hasil dari penelitian Suardika \& Surya (2016) bahwa keterlibatan pemakai berpengaruh positif dan signifikan terhadap kinerja sistem informasi akuntansi. Penelitian yang dilakukan Daryani (2013) mendapatkan hasil bahwa keterlibatan pemakai tidak berpengaruh terhadap kinerja SIA yang diukur dengan kepuasan dan pemakai. Berdasarkan uraian diatas, maka hipotesis satu dinyatakan sebagai berikut:

$\mathrm{H}_{1}$ : Keterlibatan pemakai berpengaruh positif terhadap kinerja SIA. 
Kemampuan teknis pemakai adalah tingkatan pendidikan atau pengalaman seseorang dalam menggunakan SIA. Pemakai sistem informasi yang memiliki kemampuan teknis dalam mengoperasikan suatu sistem informasi disebuah organisasi akan meningkatkan kinerja dari sistem informasi ter sebut. Tentu saja apabila pemakai sistem informasi tersebut tidak memiliki kemampuan dalam mengoperasikan sistem tersebut maka sistem informasi tersebut tidak akan beroperasi secara maksimal. Penelitian yang dilakukan oleh Choe (1996) menemukan bahwa kemampuan teknik personal sistem informasi akuntansi berpengaruh positif dan signifikan terhadap kinerja sistem informasi akuntansi. Penelitian tersebut konsisten dengan Ayu (2014) yaitu kemampuan teknik personal berpengaruh positif dan signifikan terhadap kinerja sistem informasi akuntansi. Menurut Tjhai (2002) dalam Almilia (2007) berpendapat bahwa semakin tinggi kemampuan teknik personal sistem informasi akuntansi, akan meningkatkan kinerja sistem informasi akuntansi dikarenakan adanya hubungan yang positif antara kemampuan teknik personal sistem informasi akuntansi dengan kinerja sistem informasi akuntansi. Berbeda dengan penelitian yang dilakukan oleh Jones (2008) dalam Galang (2014) yang mendapatkan hasil bahwa kemampuan teknik pemakai tidak berpengaruh terhadap kinerja sistem informasi akuntansi. Berdasarkan uraian diatas, maka hipotesis dua diny atakan sebagai berikut:

$\mathrm{H}_{2}$ : Kemampuan pemakai teknis berpengaruh postif terhadap kinerja SIA.

Pelatihan merupakan kegiatan yang bertujuan untuk memperbaiki kualitas kerja pemakai dalam menyelesaikan tugasnya. Pelatihan kerja bagi pemakai sistem informasi akuntansi tentu saja akan berpengaruh terhadap kinerja SIA, selain membantu operasional sistem juga akan meningkatkan kualitas informasi yang dihasilkan oleh sistem itu sendiri. Secara ideal pelatihan harus dirancang untuk mewujudkan tujuan organisasi, yang pada waktu bersamaan juga mewujudkan tujuan para pekerja secara perseorangan. Program pelatihan kerja bagi pemakai dapat meningkatkan kemampuan untuk mengindentifikasi persyaratan informasi mereka, kesungguhan serta keter batan SIA sehingga adanya program pendidikan dan pelatihan pemakai dapat meningkatkan kinerja SIA (Anggraini, 2012). Hasil dari penelitian oleh Sud ibyo \& Kuswanto (2010) menyatakan bahwa pelatihan kerja bagi pemakai berpengaruh signifikan terhadap kinerja sistem informasi akuntansi yang diukur dengan kepuasan pemakai pada restoran waralaba asing Kota Denpasar. Abhimantra \& Suryanawa (2016) juga mendapakan hasil yang sama yaitu pelatihan dan pendidikan pemakai berpengaruh terhadap kinerja sistem informasi akutansi. Hasil sama juga ditemukan pada penelitian yang diteliti oleh Choe (1996) dan Tjhai (2002) yang menemukan bahwa kinerja sistem infor masi akuntansi akan lebih baik jika suatu perusahaan mengadakan program pelatihan dan Pendidikan untuk pemakai sistem informasi akuntansi. Sedangkan penelitian yang dilakukan oleh Kharisma \& Juliarsa (2017) mendapatkan hasil bahwa program pelatihan kerja berpengaruh tidak signifikan terhadap kinerja sistem informasi akuntansi. Berdasarkan uraian diatas, maka hipotesis dua dinyatakan sebagai berikut:

$\mathrm{H}_{3}$ : Pelatihan Kerja pemakai sistem berpengaruh positif terhadap kinerja SIA. 


\section{METODE PENELITIAN}

Penelitian ini dilakukan di Dinas Perindustrian dan Perdagangan Kota Denpasar yang beralamat di Gedung Sewaka Dharma Lt. Ill Jl. Majapahit No. I Lumintang, Denpasar, yang dalam pelaksanaannya telah menerapkan sistem informasi akuntansi untuk mengolah data akuntansinya. Populasi dalam penelitian ini adalah pengguna sistem informasi akuntansi pada Dinas Perindustrian dan Perdagangan Kota Denpasar yang berjumlah 50 pengguna. Teknik sampling jenuh adalah teknik penentuan sampel bila semua anggota populasi digunakan sebagai sampel (Sugiyono, 2017). Sampel dalam penelitian ini berjumlah 50 pengguna.

Teknik analisis data yang digunakan dalam penelitian ini adalah analisis regresi linear berganda. Analisis regresi berganda adalah pengujian yang dilakukan untuk mengetahui ada tidaknya pengaruh keterlibatan pemakai (X1), kemampuan teknis pemakai (X2), dan pelatihan kerja pemakai (X3) pada kinerja sistem informasi akuntansi yang diukur dengan kepuasan pemakai (Y). Model regresi linear berganda ditunjukkan dalam persamaan sebagai berikut:

$Y=\alpha+\beta 1 X 2+\beta 3 X 3+e$

Keterangan:

$\mathrm{Y} \quad=$ Kinerja sistem informasi akuntansi yang diukur dengan kepuasaan pemakai

a $\quad=$ Konstan

$\mathrm{X} 1 \quad=$ Keterlibatan pemakai

$\mathrm{X} 2=$ Kemampuan teknis pemakai

X3 = Pelatihan kerja pemakai

$\beta 1=$ Koefisien regresi keterlibatan pemakai

$\beta 2=$ Koefisien regresi kemampuan teknis pemakai

$\beta 3=$ Koefisien regresi pelatihan kerja pemakai

e $\quad$ Komponen error

\section{HASIL DAN PEMBAHASAN}

Statistik deskriptif bertujuan untuk memberikan informasi mengenai karakteristik variabel - variabel penelitian yaitu jumlah nilai minimum, nilai maksimum, nilai mean, dan standar deviasi. Untuk mengukur nilai sentral dari distribusi data dapat dilakukan dengan pengukuran rata - rata (mean) sedangkan standar deviasi merpakan perbedaan nilai data yang diteliti dengan nilai rata ratanya. Hasil statistik deskriptif dapat dilihat pada Tabel 1.

Tabel 1. Hasil Statistik Deskriptif Variabel Penelitian

\begin{tabular}{lrllll}
\hline & $\mathrm{N}$ & Minimum & Maximum & Mean & Std. Deviation \\
\hline Keterlibatan pemakai & 50 & 6.00 & 16.00 & 12.52 & 2.49 \\
Kemampuan Teknis Pemakai50 & 9.00 & 16.00 & 12.76 & 1.63 \\
Program Pelatihan Kerja & 50 & 11.00 & 19.00 & 16.12 & 2.20 \\
Kinerja SIA & 50 & 14.00 & 23.00 & 18.92 & 2.14 \\
\hline
\end{tabular}

Sumber: Data Penelitian, 2019

Variabel keterlibatan pemakai memiliki nilai minimum sebesar 6 dan nilai maksimum sebesar 16. Variabel keterlibatan pemakai yang diukur dengan 4 item pernyataan dengan bantuan skala likert 4 poin memiliki nilai rata-rata sebesar 12,52, dengan nilai standar deviasi variabel keterlibatan pemakai sebesar 2,49. 
Hal ini berarti nilai standar deviasi ini lebih rendah dibandingkan dengan nilai rata-rata, yang artinya sebaran data terkait keterlibatan pemakai sudah merata.

Variabel Kemampuan teknis pemakai memiliki nilai minimum sebesar 9 dan nilai maksimum sebesar 16 . Variabel Kemampuan teknis pemakai yang diukur dengan 4 item pernyataan dengan bantuan skala likert 4 poin memiliki nilai rata-rata sebesar 12,76 dengan nilai standar deviasi variabel kemampuan teknis pemakai sebesar 1,63. Hal ini berarti nilai standar deviasi lebih rendah dibandingkan dengan nilai rata-rata, yang artinya sebaran data terkait dengan kemampuan teknis pemakai sudah merata.

Variabel Pelatihan kerja pemakai memiliki nilai minimum sebesar $11 \mathrm{~d}$ an nilai maksimum sebesar 19. Variabel Pelatihan kerja pemakai yang diukur dengan 5 item pernyataan dengan bantuan skala likert 4 poin memiliki nilai ratarata sebesar 16,12, dengan nilai standar deviasi variabel Pelatihan kerja pemakai sebesar 2,209. Hal ini berarti nilai standar deviasi ini lebih rendah dibandingkan dengan nilai rata-rata, yang artinya sebaran data terkait sudah merata.

Variabel kinerja sistem informasi akuntansi memiliki nilai minimum sebesar 14 dan nilai maksimum sebesar 23. Variabel kinerja sistem informasi akuntansi yang diukur dengan 8 item pernyataan dengan bantuan skala likert 4 poin memiliki nilai rata-rata sebesar 18,92, dengan nilai standar deviasi variabel kinerja sistem informasi akuntansi sebesar 2,14. Hal ini berarti nilai ini lebih rendah dibandingkan dengan nilai rata-rata, yang artinya sebaran data terkait sudah merata.

Perhitungan koefisien regresi linier berganda dilakukan dengan analisis regresi melalui software SPSS 18.0 for Windows, diperoleh hasil yang ditunjukan pada Tabel 2.

Tabel 2. Hasil Analisis Regresi Linier Berganda

\begin{tabular}{llllll}
\hline Model & \multicolumn{2}{l}{$\begin{array}{l}\text { Unstandardized } \\
\text { Coefficients }\end{array}$} & \multicolumn{2}{l}{$\begin{array}{l}\text { Standardized } \\
\text { Coefficients }\end{array}$} & \\
\cline { 2 - 4 } & B & Std. Error & Beta & T & Sig. \\
\hline 1 (Constant) & 5.152 & 1.743 & & 2.955 & .005 \\
Keterlibatan pemakai & .261 & .106 & .303 & 2.457 & .018 \\
Kemampuan TeknisPemakai & .341 & .135 & .260 & 2.532 & .015 \\
ProgramPelatihan Kerja & .381 & .128 & .392 & 2.970 & .005 \\
\hline
\end{tabular}

Sumber: Data Penelitian, 2019

Berdasarkan hasil analisis regresi linier berganda seperti yang disajikan pada Tabel 2. maka dapat dibuat persamaan regresi sebagai berikut:

$$
Y=5,152+0,261 X_{1}+0,341 X_{2}+0,381 X_{3}
$$

Nilai koefisien regresi masing-masing variabel bebas bernilai positif dengan nilai signifikansi uji t kurang dari 0,05. Hal ini menunjukkan bahwa semua variabel bebas memiliki pengaruh positif yang signifikan terhadap variabel terikat.

Koefisien determinasi $\left(R^{2}\right)$ digunakan untuk mengetahui dan mengukur kemampuan model dalam menerangkan variasi variabel independen. Peneliti menggunakan nilai adjusted $\mathrm{R}^{2}$ pada saat mengevaluasi yang mana model regresi terbaik, karena tidak seperti $R^{2}$, nilai adjusted $R^{2}$ dapat naik atau tur un apabila satu variabel independen ditambahkan ke dalam model. 
Tabel 3. Hasil Uji Koefisien Determinasi $\left(\mathbf{R}^{2}\right)$

\begin{tabular}{clllll}
\hline Model & & & & Std. Error of the \\
& $\mathrm{R}$ & RSquare & Adjusted RSquare & Estimate & \\
\hline 1 & $.786^{\mathrm{a}}$ & .617 & .592 & 1.37053 & \\
\hline
\end{tabular}

Sumber: Data Penelitian, 2019

Hasil uji pada Tabel 3. memberikan hasil dimana diperoleh besarnya adjusted $\mathrm{R}^{2}$ (koefisien determinasi yang telah disesuaikan) adalah sebesar 0,592. Hal ini menunjukkan bahwa variasi kinerja sistem informasi akuntansi pada Dinas Perindustrian dan Perdagangan Kota Denpasar dapat dipengaruhi secara signifikan oleh variabel keterlibatan, kemampuan teknis, dan pelatihan kerja pemakai, sebesar 54,4 persen, sedangkan sisanya sebesar 45,6 persen dijelaskan oleh faktor-faktor lain yang tidak dijelaskan dalam model penelitian.

Uji ketepatan model regresi bertujuan untuk mengetahui a pakah semua variabel bebas yang diidentifikasi (keterlibatan, kemampuan teknis, dan pelatihan kerja pemakai) tepat digunakan memprediksi kinerja sistem informasi akuntansi pada Dinas Perindustrian dan Perdagangan Kota Denpasar. Hasil Uji F dalam penelitian ini dapat dilihat pada Tabel 4. berikut.

Tabel 4. Hasil Uji F

\begin{tabular}{lllllll}
\hline Model & & Sum of Squares & $d f$ & Mean Square & F & Sig. \\
\hline 1 & Regression & 139.275 & 3 & 46.425 & 24.716 & $.000^{\text {a }}$ \\
& Residual & 86.405 & 46 & 1.878 & & \\
& Total & 225.680 & 49 & & & \\
\hline
\end{tabular}

Sumber: Data Penelitian, 2019

Hasil uji $\mathrm{F}$ (Ftest) pada Tabel 4. menunjukkan bahwa nilai signifikansi $\mathrm{P}$ value 0,000 yang lebih kecil dari $a=0,05$, ini berarti model yang digunakan pada penelitian ini adalah layak. Hasil ini memberikan makna bahwa seluruh variabel independen mampu memprediksi atau menjelaskan fenomena kinerja sistem informasi akuntansi pada Dinas Perindustrian dan Perdagangan Kota Denpasar . Hal ini berarti model dapat digunakan untuk analisa lebih lanjut atau dengan kata lain model dapat digunakan untuk memproyeksikan karena hasil goodness of fitnya baik dengan nilai signifikansi P value 0,000.

Hasil analisis dalam penelitian ini menunjukkan bahwa keterlibatan pemakai berpengaruh positif terhadap kinerja sistem informasi akuntansi. Hal ini berarti bahwa semakin tinggi keterlibatan karyawan dalam menggunakan sistem informasi akuntansi, maka akan semakin meningkatkan kinerja penggunaan sistem informasi akuntansi pada Dinas Perindustrian dan Perdagangan Kota Denpasar. Begitu juga sebaliknya semakin rendah keterlibatan karyawan dalam menggunakan sistem informasi akuntansi, maka akan semakin mengurangi keefektifan kinerja penggunaan sistem informasi akuntansi pada Dinas Perindustrian dan Perdagangan Kota Denpasar.

Penelitian ini sesuai dengan temuan Komara (2005) dan Ayu (2014) yang menemukan bahwa keterlibatan pemakai dalam pengembangan sistem informasi akuntansi berpengaruh positif terhadap kinerja sistem informasi akuntansi. Artinya semakin tinggi keterlibatan pemakai, maka semakin baik pula kinerja SIA yang dihasilkan oleh organisasi. Dengan demikian keberadaan keterlibatan pemakai yang kuat sangat dibutuhkan oleh organisasi agar dapat meningkatkan kinerja SIA yang akan dihasilkan. Hasil penelitian ini juga mendukung oleh 
beberapa hasil penelitian sebelumnya dan konsisten dengan hasil penelitian Tjhai (2002), Acep (2005), Suardika \& Surya (2016) yang memperoleh hasil bahwa keterlibatan pemakai berpengaruh positif dan signifikan terhadap kinerja sistem informasi akuntansi, hal ini berarti bahwa semakin tinggi keterlibatan pemakai akan menyebabkan meningkatnya kinerja sistem informasi akuntansi. Sistem informasi akuntansi tidak akan menghasilkan informasi bagi perusahaan apabila tidak ada pemakai yang mengoperasikan sistem tersebut. Oleh karena itu keterlibatan pemakai sistem informasi sangat diperlukan agar sistem informasi dapat beroperasi secara maksimal.

Kinerja sistem informasi akuntansi pada Dinas Perindustrian dan Perdagangan Kota Denpasar akan semakin meningkat apabila karyawannya memiliki keterlibatan yang tinggi untuk berpartisipasi dalam pengembangan SIPKD, bersedia menggunakan SIPKD yang dioperasikan, terlibat dalam perencanaan SIPKD yang dioperasikan, dan ikut terlibat dalam mengidentifikasi masalah dalam SIPKD yang dioperasikan. Keterlibatan pemakai dalam TAM dikenal sebagai intention yang dalam pemikiran Davis (1989) dan Pantono (2012) terjadi karena perceived usefulness dan perceived ease off use.

Keterlibatan pengguna merupakan keterlibatan dalam penggunaan dan masuk juga dalam proses pengembangan sistem oleh anggota organisasi atau anggota dari kelompok pengguna target. Hasil penelitian ini mengkonfirmasi dan memberikan tambahan bukti empiris pada teori Technology Acceptance Model (TAM). Keterlibatan pemakai yang mencerminkan minat menggunakan sistem informasi muncul dari persepsi kemanfaatan dan persepsi kemudahan pengguna, terbukti mampu meningkatkan kinerja sistem informasi akuntansi. Teori TAM merupakan suatu teori yang menjelaskan model sikap individu dalam menerima dan menggunakan teknologi. Technology Acceptance Model (TAM) menjelaskan bahwa terdapat dua faktor yang memengaruhi perilaku personal untuk menerima dan menggunakan teknologi. Dua faktor tersebut adalah persepsi kemanfaatan dan persepsi kemudahan dalam penggunaan teknologi (Surendran, 2012). Berdasarkan teori ini keterlibatan pengguna dalam menggunakan SIA didalam sebuah organisasi sangat diperlukan dalam meningkatkan kinerja SIA. Temuan penelitian menunjukkan hasil yang mendukung TAM bahwa kinerja SIA yang baik membutuhkan keterlibatan pemakai. Oleh karena itu dalam upaya meningkatkan kinerja SIA di Dinas Perindustrian dan Perdagangan Kota Denpasar dapat dilakukan dengan meningkatkan keterlibatan pemakai atau operator.

Hasil analisis dalam penelitian ini menunjukkan bahwa kemampuan teknis pemakai berpengaruh positif terhad ap kinerja sistem informasi akuntansi. Hal ini berarti bahwa apabila pegawai memiliki kemampuan teknis menggunakan sistem informasi akuntansi yang tinggi maka kinerja sistem informasi akuntansi yang dihasilkan akan semakin tinggi, begitu pula sebaliknya semakin rendah kemampuan karyawan dalam menggunakan sistem informasi akuntansi maka tingkat kinerja sistem informasi akuntansi yang dihasilkan akan semakin rendah.

Penelitian ini sesuai dengan temuan Ayu (2014) yang memperoleh hasil bahwa kemampuan teknis personal berpengaruh positif dan signifikan terhadap kinerja sistem informasi akuntansi.. Semakin tinggi tingkat Kemampuan teknis 
pemakai maka kinerja sistem informasi akuntansi akan semakin meningkat. Hasil penelitian ini juga mendukung hasil penelitian Almilia (2007) yang berpendapat bahwa semakin tinggi kemampuan teknik personal sistem informasi akuntansi, akan meningkatkan kinerja sistem informasi akuntansi dikarenakan adanya hubungan yang positif antara kemampuan teknik personal sistem informasi akuntansi.

Semakin tinggi kemampuan teknis pegawai Dinas Perindustrian dan Perdagangan Kota Denpasar khususnya pada pegawai di bidang perbendaharaan, akuntansi, pelaporan keuangan dalam menggunakan sistem informasi akuntansi, maka akan mampu meningkatkan kinerja sistem informasi akuntansi menjadi lebih optimal. Kemampuan teknis pegawai tersebut dapat ditingkatkan melalui pemahaman informasi akuntansi yang baik, meningkatkan kemampuan teknis dalam menggunakan akuntansi, dan mengikuti pendidikan personal. Kemampuan teknis pemakai dalam TAM dikenal sebagai perceived of use yang dalam pemikiran Davis (1989).

Kemampuan teknis pemakai sistem informasi adalah kemampuan individu untuk mengoperasikan sistem informasi akuntansi yang digunakan. Hasil penelitian ini mengkonfirmasi dan memberikan tambahan bukti empiris pada teori TAM. Kemampuan teknis pemakai yang mencerminkan kemudahan penggunaan sistem informasi terbukti mampu meningkatkan kinerja sistem informasi akuntansi. Teori TAM merupakan suatu teori yang menjelaskan model sikap individu untuk menerima dan menggunakan teknologi. Technology Acceptance Model (TAM) menjelaskan bahwa terdapat dua faktor yang memengaruhi perilaku personal untuk menerima dan menggunakan teknologi. Dua faktor tersebut adalah persepsi kemanfaatan dan persepsi kemudahan dalam penggunaan teknologi (Surendran, 2012). Berdasarkan teori ini kemampuan teknis pemakai dalam menggunakan SIA didalam sebuah organisasi sangat diperlukan dalam meningkatkan kinerja SIA. Temuan penelitian menunjukkan hasil yang mendukung TAM bahwa kinerja SIA yang baik membutuhkan kemampuan teknis pemakai. Oleh karena itu dalam upaya meningkatkan kinerja SIA di Dinas Perindustrian dan Perdagangan Kota Denpasar dapat dilakukan dengan meningkatkan kemampuan teknis pemakai atau operator.

Hasil analisis dalam penelitian ini menunjukkan bahwa pelatihan kerja pemakai berpengaruh positif terhadap kinerja sistem informasi akuntansi. Hal ini berarti bahwa semakin tinggi pelatihan kerja karyawan dalam menggunakan sistem informasi akuntansi, maka akan semakin meningkatkan kinerja penggunaan sistem informasi akuntansi pada Dinas Perindustrian dan Perdagangan Kota Denpasar. Begitu juga sebaliknya semakin rendah pelatihan kerja karyawan dalam menggunakan sistem informasi akuntansi, maka akan semakin mengurangi keefektifan kinerja penggunaan sistem informasi akuntansi pada Dinas Perindustrian dan Perdagangan Kota Denpasar.

Penelitian ini sesuai dengan temuan Sudibyo \& Kuswanto (2010) yang menyatakan bahwa pelatihan kerja bagi pemakai berpengaruh signifikan terhadap kinerja sistem informasi akuntansi. Artinya semakin tinggi pelatihan kerja pemakai, maka semakin baik pula kinerja yang dihasilkan oleh organisasi. Hasil penelitian ini juga mendukung oleh beberapa hasil penelitian sebelumnya 
dan konsisten dengan hasil penelitian Abhimantra \& Suryanawa (2016) yang juga mendapakan hasil yang sama yaitu pelatihan dan pendidikan pemakai berpengaruh terhadap kinerja sistem informasi akutansi, hal ini berarti bahwa semakin tinggi pelatihan kerja pemakai akan menyebabkan meningkatnya kinerja sistem informasi akuntansi. Hasil sama juga ditemukan pada penelitian yang diteliti oleh Choe (1996) dan Tjhai (2002) yang menemukan bahw a kinerja sistem informasi akuntansi akan lebih baik jika suatu perusahaan mengadakan program pelatihan dan pendidikan untuk pemakai sistem informasi akuntansi.

Kinerja sistem informasi akuntansi pada Dinas Perindustrian dan Perdagangan Kota Denpasar akan semakin meningkat apabila organisasi menyelenggarakan program pelatihan kerja pemakai sistem informasi akuntansi, terutama mengenai SIPKD, kemudian menyediakan instruktur program pelatihan kerja pemakai SIPKD yang berkualitas, lalu materi yang diberikan dalam program pelatihan kerja SIPKD membantu karyawan dalam menyelesaikan pekerjaan, mengembangkan pengetahuan dan keterampilan yang dimiliki karyawan. Pelatihan kerja pemakai dalam TAM dikenal sebagai perceived usefulness yang dalam pemikiran (Davis, 1989).

Pelatihan Kerja Pemakai merupakan pelatihan yang diselenggarakan oleh pihak perusahaan untuk memperkenalkan sistem kepada karyawannya. Hasil penelitian ini mengkonfirmasi dan memberikan tambahan bukti empiris pada teori Technology Acceptance Model (TAM). Pelatihan kerja pemakai yang mencerminkan perceived usefulness menggunakan sistem informasi terbukti mampu meningkan kinerja SIA. Teori TAM merupakan suatu teori yang menjelaskan model sikap individu dalam menerima dan menggunakan teknologi. Technology Acceptance Model (TAM) menjelaskan bahwa terda pat dua faktor yang memengaruhi perilaku personal untuk menerima dan menggunakan teknologi. Dua faktor tersebut adalah persepsi kemanfaatan dan persepsi kemudahan dalam penggunaan teknologi (Surendran, 2012). Berdasarkan teori ini pelatihan kerja pemakai dalam menggunakan SIA didalam sebuah organisasi sangat diperlukan dalam meningkatkan kinerja SIA. Temuan penelitian menunjukkan hasil yang mendukung TAM bahwa kinerja SIA yang baik membutuhkan pelatihan kerja pemakai. Oleh karena itu dalam upaya meningkatkan kinerja SIA di Dinas Perindustrian dan Perdagangan Kota Denpasar dapat dilakukan dengan meningkatkan pelatihan kerja pemak ai atau operator.

Pelatihan merupakan kegiatan yang bertujuan untuk memperbaiki kualitas kerja pemakai dalam menyelesaikan tugasnya. Pelatihan bagi pemakai sistem informasi akuntansi tentu saja akan berpengaruh terhadap kinerja SIA, selain membantu operasional sistem juga akan meningkatkan kualitas informasi yang dihasilkan oleh sistem itu sendiri. Secara ideal pelatihan harus dirancang untuk mewujudkan tujuan organisasi, yang pada waktu bersamaan juga mewujudkan tujuan para pekerja secara perseorangan. Program pelatihan kerja bagi pemakai dapat meningkatkan kemampuan untuk mengindentifikasi persyaratan informasi mereka, kesungguhan serta keterbatan SIA sehingga adanya program pendidikan dan pelatihan pemakai dapat meningkatkan kinerja SIA (Anggraini, 2012). 


\section{SIMPULAN}

Penelitian yang dilakukan diharapkan dapat memberikan kontribusi mengenai pengaruh keterlibatan, kemampuan teknis, pelatihan kerja pemakai pada kinerja sistem informasi akuntansi. Hasil uji hipotesis dalam penelitian ini ditemukan bahwa keterlibatan, kemampuan teknis, pelatihan kerja pemakai secara statistik mampu berpengaruh positif terhadap kinerja sistem informasi akuntansi Pada Dinas Perindustrian dan Perdagangan Kota Denpasar, sehingga hasil tersebut sesuai dengan teori TAM. Berdasarkan teori ini menggambarkan bahwa keterlibatan, kemampuan teknis, dan pelatihan kerja pemakai dalam menggunakan SIA dididalam organisasi sangat diperlukan karena semakin tinggi tingkat keterlibatan, kemampuan teknis, dan pelatihan kerja pemakai pada Dinas Perindustrian dan Perdagangan Kota Denpasar dalam menggunakan SIA, maka efektivitas kinerja atas pengunaan SIA pada Dinas Perindustrian dan Perdagangan Kota Denpasar akan semakin meningkat. Penelitian ini memberikan implikasi bagi Dinas Perindustrian dan Perdagangan Kota Denpasar sebagai pertimbangan dan pengetahuan mengenai keefektifan pengunaan sistem informasi akuntansi serta faktor-faktor yang memengaruhinya. Perusahaan dapat mengevaluasi dan meningkatkan tingkat keterlibatan, kemampuan teknis, dan pelatihan kerja pemakai dalam menggunakan sistem informasi akuntansi, karena hal tersebut dapat mempengaruhi keefektifan pengunaan sistem informasi akuntansi di Dinas Perindustrian dan Perdagangan Kota Denpasar.

\section{REFERENSI}

Abhimantra dan Suryanawa. (2016). Analisis Faktor-Faktor Yang Memengaruhi Kinerja Sistem Informasi Akuntansi. E-Jurnal Akuntansi, 14(3), 17821809.

Acep, K. (2005). Analisis Faktor-Faktor yang Mepengaruhi Kinerja Sistem Informasi Akuntansi. Jurnal Ilmiah Universitas Swadaya Gunung Jati. Cirebon.

Almilia, L. S. (2007). Faktor-Faktor Yang Mempengaruhi Kinerja Sistem Informasi Akuntansi Pada Bank Umum Pemerintah Di Wilayah Surabaya Dan Sidoarjo.

Anggraini. (2012). Faktor-Faktor Yang Mempengaruhi Kinerja Sistem Infor masi Akuntansi Di Lingkungan Pemerintahan Daerah Serdang Bedagai. Jurnal Telaah Akuntansi, 14(2), 16-30.

Artanaya. (2016). Pengaruh Partisipasi Pemakai Terhadap Kinerja Sistem Informasi Akuntansi Dengan Kemampuan Pemakai Sebagai Variabel Moderasi. E-Jurnal Akuntansi, 15(2), 1482-1509.

Ayu, P. (2014). Analisis Faktor-Faktor Yang Mempengaruhi Kinerja Sistem Informasi Akuntansi Pada Lpd Di Kecamatan Denpasar Utara.

Aziz, K. (2003). Accounting information system satisfaction and job satisfaction among Malaysian accountants. PACIS Proceedings, 786-802

Azhar, L. M. dan Susanto. (2001). Sistem Informasi Akuntansi I dan II. Edisi Ke Sebelas. Bandung: Lembaga Informasi.

Bastian, Indra. (2009). Akuntansi Sektor Publik di Indonesia. Yogyakarta: BPFE UGM. 
Bodnar, G. H., and Hopwood, W. S. (2010). Accounting Information System. Tenth Edition. Pearson Education Inc.

Choe, J. M. (1996). The relationships among performance of accounting information systems, influence factors, and evolution level of information systems. Journal of Management Information Systems.

Daryani. (2013). Faktor-Faktor Yang Mempengaruhi Kinerja Sistem Informasi Akuntansi (Survei pada Bank Perkreditan Rakyat di Kabupaten Boyolali). Naskah Publikasi.

Dasgupta. (2002). User acceptance of e-collaboration technology: An extension of the technology acceptance model. Group Decision and Negotiation, 11(2), 87-100.

Ghozali, Imam. (2013). Aplikasi Analisis Multivariate dengan Program IBM SPSS 21 Update PLS Regresi. Semarang: Badan Penerbit Universitas Diponegoro.

Greenberg, Jerald. (2011). Behavior in Organization. 10th edition. London: Pears on Education.

Gupta, M. P., Kanungo, S., Kumar, R., and Sahu, G. P. (2007). A Study of Information Technology Effectiveness in Select Government Organizations in India. Journal for Decision Makers, 32(2).

Hadjar, Ibnu. (1999). Dasar-dasar Metodologi Penelitian Kwantitatif Dalam Pendidikan. Jakarta: Raja Grafindo Persada.

Handayani, R. (2010). Analisis Faktor-Faktor yang Menentukan Fektivitas Sistem Informasi pada Organisasi Sektor Publik. Jurnal Akuntansi Dan Keuangan, 12(1), 26-40.

Harash. (2014). The Influence of Finance on Performance of Small and Medium Enterprises (SMES). International Journal of Engineering and Innovative Technology, 4(3), 161-167.

Hendarti, H., dan Gui, A. (2008). Korelasi Antara Efektifitas Sistem Informasi Penjualan Dengan Kinerja User. Simposium Nasional Akuntansi (SNA) KE XI Pontianak.

Hutama, R. C. (2017). Pengaruh Keterlibatan Pemakai Sistem, Program Pelatian Dan Pendidikan, Kemampuan Teknik Personal, Dukungan Manajemen Puncak, Dan Formalisasi Pengembangan Sistem Informasi Terhadap Kinerja Sistem Informasi Akuntansi Di Bank Umum Kota Surakarta. 18(1), 18-31.

Ikhsan, Arfan. (2008). Metodologi Penelitian Akuntansi Keperilakuan. Yogyakarta: Graha Ilmu.

Janella, Rose. (2006). Ease of Use in the Technology Acceptance Model : Academy of World Business. Marketing \& Management Development Conference Proceedings, 2(10), 122-129.

Jogiyanto. (2005). Sistem Teknologi Informasi. Yogyakarta: Andi Offset.

Kharisma, I. A. M., dan Juliarsa, G. (2017). Pengaruh Keterlibatan Pemakai, Kemampuan Pemakai, Pelatihan Dan Pendidikan Pemakai Terhadap Kinerja Sistem Informasi Akuntansi. E-Jurnal Akuntansi Universitas Udayana, 19(3), 2527-2555.

Komara. (2005). Analisis Faktor-Faktor Yang Mempengaruhi Kinerja Sistem Informasi Akuntansi Drs. Acep. Seminar Nasional Akuntansi VIII, 15-16. 
Komara. (2016). Analisis Faktor-Faktor Yang Mempengaruhi Kinerja Sistem Informasi Akuntansi. Jurnal Riset Akuntansi Dan Manjemen, 2(1), 55-63.

Kumar. (2016). State of green marketing research over 25 years (1990-2014): Literature survey and classification. Marketing Intelligence and Planning, 34(1), 137-158.

Luh, N., dan Sherina, N. (2014). Analisis technology acceptance model (tam) terhadap penggunaan sistem informasi di nusa indah beach hotel \& spa, E-Jurnal Akuntansi Universitas Udayana, 1, 167-184.

McCloskey. (2011). The Importance of Ease of Use, Usefulness, and Trust to Online Consumers. Journal of Organizational and End User Computing, 18(3), 47-65.

Meiryani. (2014). Pengaruh kualitas sistem, pemanfaatan sistem informasi dan minat pengguna accurate terhadap kinerja individu. Jurnal Akuntansi Dan Keuangan, 8(1), 1-16.

Mohd. (2011). Extending the Technology Acceptance Model to Account for Social Influence, Trust and Integration for Pervasive Computing Environment : A Case Study in University Industry. American Journal of Economics and Business Administration, 3(3), 552-559.

Napitupulu. (2015). Antecedence of user satisfaction in management accounting information systems quality: User involvement and user competency (survey of Indonesia manufacture company managers). International Journal of Applied Business and Economic Research, 13(2), 561-577.

Pantano, E., and Di Pietro, L. (2012). Understanding consumer's acceptance of technology-based innovations in retailing. Journal of Technology Management and Innovation, 7(4), 1-19.

Puspitasari dan Juliarsa. (2017). Keterlibatan Dan Kemampuan Teknik PersonalEra globalisasi, ketatnya persaingan antar perusahaan mendorong setiap perusahaan untuk menerapkan sistem informasi yang dapat mendukung kemampuan operasional perusahaan secara efektif, efisien, dan terkendali. 20,380-408.

Rivai, Veithzal. (2004). Manajemen Sumber Daya Manusia Untuk Perusahaan: Dari Teori ke Praktik. Jakarta: Raja Grafindo Persada.

Robbins. (1965). Organizational Behavior. The British Journal of Psychiatry, 111.

Rusmiati, Rusi. (2012). Pengaruh Keterlibatan Pemakai, Kapabilitas Personal Sistem Informasi, Ukuran Organisasi dan Formalisasi Pengembangan Sistem Informasi Terhadap Kepuasan Pemakai Sistem Informasi Akuntansi. Skripsi Akuntansi Universitas Pasundan.

Stephen, P. R. (2009). Perilaku Organisasi. Jakarta: Salemba Empat.

Suardika dan Surya. (2016). Faktor-faktor yang berpengaruh pada kepuasan pemakai sistem informasi akuntansi lembaga perkreditan desa di Kecamatan Mengwi. E-Jurnal Akuntansi, 15, 317-348.

Sugiyono. (2017). Pendekatan Kuantitatif, Kualitatif, Kombinasi, RED dan Penelitian Evaluasi.

Surendran. (2012). Technology Acceptance Model: A Survey of Literature. International Journal of Business and Social Research, 2(4), 175-178. 
Susilatri. (2010). Faktor-Faktor Yang Mempengaruhi Kinerja Sistem Informasi Akuntansi Pada Bank Umum Pemerintah di Kota Pekanbaru. Jumal Ekonomi, 18, 133-141.

Tjhai, F. J. (2002). Faktor-Faktor Yang Mempengaruhi Kinerja Sistem Infor masi Akuntansi. Jurnal Bisnis dan Akuntansi, 4(2).

Wulandari, P. S., dan Juliarsa, G. (2017). Pengaruh Dukungan Manajemen Puncak, Keterlibatan Pengguna, Program Platihan Pada Bpr Di Kediri. 19, 1290-1319.

Wilkinson, J. W. (2000). Accounting Information System. Frouth Edition. United States New York: John Wiley and Sons In. 